\title{
Implementasi Metode RELU, SIGMOID, MSE, Dan SGD Dalam Memprediksi Tingkat Pemahaman Siswa/I Pada Mata Pelajaran Pemrograman Di SMKS Mustafa Perbaungan
}

\author{
Annas Prasetio $^{1}$, Muhammad Hari Hasibuan ${ }^{2}$, Primatua Sitompul ${ }^{3}$ \\ 1,2,3 Magister Ilmu Komputer Universitas Potensi Utama Medan \\ Jl. KL Yos Sudarso KM 6.5 No. 3 A, Tanjung Mulia, Medan Deli, 20241 \\ Corresponding author's e-mail: annasprasetio45@gmail.com
}

\begin{abstract}
Abstrak - Didalam dunia pendidikan, pencapaian akademik sangat diharuskan bagi siswa/i untuk semua mata pelajaran yang ada disekolah. Pencapaian akademik merupakan salah satu yang dianggap sebagai suatu keberhasilan siswa/I dalam memahami pelajaran yang diberikan. Salah satu mata pelajaran yang akan diprediksi tingkat pemahamannya adalah mata pelajaran pemrograman di SMKS Mustafa Perbaungan. Dalam penelitian ini menggunakan data sampel 5 siswa/I dengan menggunakan beberapa kriteria seperti pengetahuan, keterampilan, tugas yang diberikan dan antusias. Metode yang diterapkan adalah kombinasi dari metode $R E L U$, SIGMOID, MSE dan SGD. Adapun hasil dari penelitian ini adalah dengan menggunakan hasil keputusan memahami dan cukup memahami. Penelitian ini masih berupa rancangan sehingga diharapkan dapat memberikan gambaran dalam menerapkan metode Deep Learning untuk memprediksi tingkat pemahaman siswa/I di sekolah.
\end{abstract}

Kata kunci: Prediksi, RELU, SIGMOID, MSE, SGD.

\section{Pendahuluan}

Didalam dunia pendidikan, pencapaian akademik sangat diharuskan bagi siswa/i untuk semua mata pelajaran yang ada disekolah. Pencapaian akademik merupakan salah satu hal yang dianggap sebagai suatu keberhasilan siswa/I dalam memahami pelajaran yang diberikan. Salah satu mata pelajaran yang akan diprediksi tingkat pemahamannya adalah mata pelajaran pemrograman di SMKS Mustafa Perbaungan.

Proses belajar mengajar merupakan salah satu kegiatan di sekolah yang bertujuan untuk mencerdaskan anak bangsa. Dalam kegiatan proses belajar mengajar di sekolah tidak terlepas dari tenaga pengajar yang profesional dan pemahaman siswa, serta perlunya hubungan dua arah antara siswa dengan tenaga pengajar. Hal ini bertujuan agar selama dalam proses belajar mengajar tercipta kerjasama yang baik antara tenaga pengajar dan siswa. Terutama dalam mata pelajaran yang masuk dalam kompetensi keahlian kejuruan Teknik Komputer dan Jaringan (TKJ), salah satunya yaitu mata pelajaran Pemrograman Dasar.

Dalam penelitian ini menggunakan data sampel 5 siswa/I dengan menggunakan beberapa kriteria seperti pengetahuan, keterampilan, tugas yang diberikan dan antusias. Metode yang diterapkan adalah kombinasi dari metode RELU, SIGMOID, MSE dan SGD. Adapun hasil dari penelitian ini adalah dengan menggunakan hasil keputusan memahami dan cukup memahami. Penelitian ini masih berupa rancangan sehingga diharapkan dapat memberikan gambaran dalam menerapkan metode Deep Learning untuk memprediksi tingkat pemahaman siswa/I di sekolah.

\section{Tinjauan Pustaka}

2.1. Pendidikan

Menurut Illich dalam Sholichah (2018:27), pendidikan adalah proses memberikan manusia berbagai macam situasi yang bertujuan memberdayakan diri dengan dengan mempertimbangkan aspek penyadaran, pencerahan, pemberdayaan, dan perubahan perilaku. Hal ini memberikan isyarat perlunya mempersiapkan generasi yang dapat menciptakan peluang kerja dengan berbagai keterampilan dan pengetahuan yang dimiliki dengan tetap menjadikan pendidikan moral sebagai prioritas.

Menurut Pratiwi (2015:76), Pendidikan merupakan proses sistematis yang melibatkan baik faktor internal maupun eksternal. Faktor internal adalah faktor yang datang dari diri siswa, antara lain minat belajar, motivasi belajar, bakat, dan persepsi, baik persepsi siswa terhadapat mata pelajaran maupun terhadap guru pengajar. Selain itu juga ada faktor eksternal, yaitu faktor yang datang dari luar diri siswa, seperti lingkungan belajar, lingkungan keluarga, latar belakang sosial ekonomi keluarga, dan perhatian orang tua dalam membantu mengatasi kesulitan belajar yang dialami anak.

2.2. Prestasi 
Menurut Poerwodarminto dalam Hidayat (2013:83) yang dimaksud dengan prestasi adalah hasil yang telah dicapai, dilakukan atau dikerjakan oleh seseorang. Sedangkan prestasi belajar itu sendiri diartikan sebagai prestasi yang dicapai oleh seorang siswa pada jangka waktu tertentu dan dicatat dalam buku rapor sekolah.

Menurut Pratiwi (2015:81), Prestasi belajar merupakan hasil yang diperoleh seseorang dalam belajar sesuai kapasitas (kemampuan, kecakapan, dan kesanggupan) yang dimilikinya. Kapasitas yang terdapat dalam individu antara lain intelegensi, bakat, minat, dan motivasi yang semuanya itu memengaruhi pencapaian belajar yang maksimal. Prestasi belajar adalah kecakapan nyata atau aktual yang menunjukan adanya aspek kecakapan yang segera didemonstrasikan dan diujikan karena merupakan hasil usaha belajar yang dicapai di sekolah baik berupa pengetahuan, sikap, atau keterampilan yang dimanifestasikan dalam bentuk nilai.

2.3 Deep Learning

Menurut Ilahiyah, dan Agung Nilogiri (2018:49), Deep Learning adalah cabang ilmu machine learning berbasis Jaringan Saraf Tiruan (JST) atau bisa dikatakan sebagai perkembangan dari JST. Dalam deep learning, sebuah komputer belajar mengklasifikasi secara langsung dari gambar atau suara.

Deep Learning merupakan salah satu bidang dari machine learning yang memanfaatkan jaringan syaraf tiruan untuk implementasi permasalahan dengan dataset yang besar. Teknik deep learning memberikan arsitektur yang sangat kuat untuk supervised learning. Dengan menambahkan lebih banyak lapisan maka model pembelajaran tersebut bisa mewakili data citra berlabel dengan lebih baik.

Pada machine learning terdapat teknik untuk menggunakan ekstraksi fitur dari data pelatihan dan algoritma pembelajaran khusus untuk mengklasifikasi citra. maupun untuk mengenali suara. Namun, metode ini masih memiliki beberapa kekurangan baik dalam hal kecepatan dan akurasi. Aplikasi konsep jaringan syaraf tiruan yang dalam (banyak lapisan) dapat ditangguhkan pada algoritma machine learning yang sudah ada sehingga komputer sekarang bisa belajar dengan kecepatan, akurasi, dan skala yang besar[14]. Prinsip ini terus berkembang hingga deep learning semakin sering digunakan pada komunitas riset dan industri untuk membantu memecahkan banyak masalah data besar seperti Computer vision, Speech recognition, dan Natural Language Processing. Feature Engineering adalah salah satu fitur utama dari deep learning untuk mengekstrak pola yang berguna dari data yang akan memudahkan model untuk membedakan kelas. Feature Engineering juga merupakan teknik yang paling penting untuk mencapai hasil yang baik pada tugas prediksi. Namun, sulit untuk dipelajari dan dikuasai karena kumpulan data dan jenis data yang berbeda memerlukan pendekatan teknik yang berbeda juga. Didalam Deep Learning terdapat beberapa metode diantaranya; ReLU, Sigmoid, MSE, dan SGD.

\section{ReLU}

Aktivasi ReLU (Rectified Linear Unit) merupakan lapisan aktivasi pada model CNN yang mengaplikasikan fungsi $\mathrm{f}(\mathrm{x})=\max (0, \mathrm{x})$ yang berarti fungsi ini melakukan thresholding dengan nilai nol terhadap nilai piksel pada input citra. Aktivasi ini membuat seluruh nilai piksel yang bernilai kurang dari nol pada suatu citra akan dijadikan 0 .

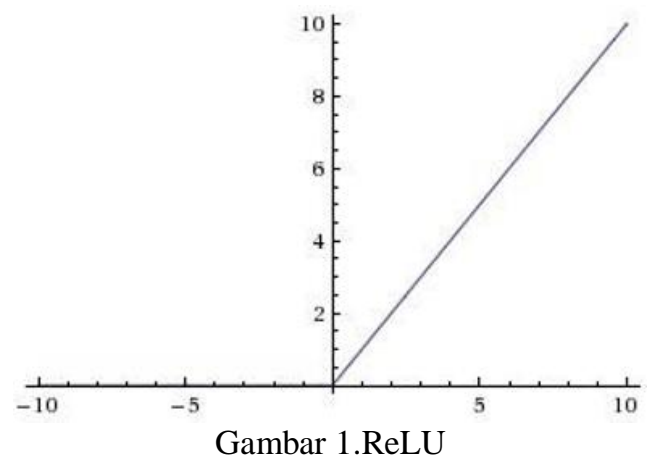

\section{Sigmoid}

Sigmoid function mempunyai rentang antara 0 hingga 1 sedangkan rentang dari Tanh adalah -1 hingga 1. Kedua fungsi ini biasanya digunakan untuk klasifikasi 2 class atau kelompok data. 


\section{MSE}

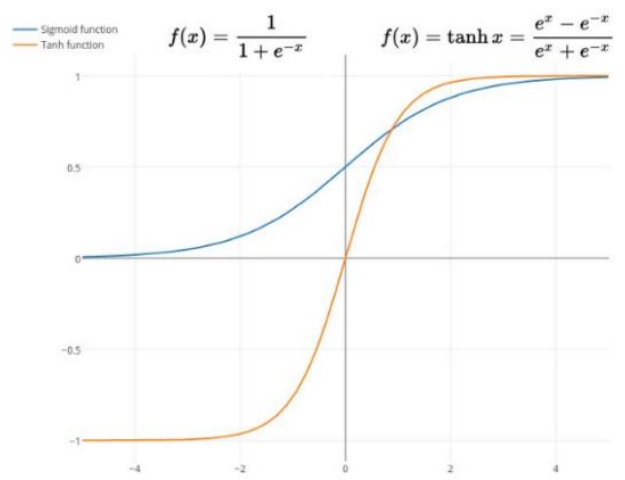

Gambar 2. Sigmoid

Mean Squared Error (MSE) adalah metode lain untuk mengevaluasi metode peramalan. Masingmasing kesalahan atau sisa dikuadratkan. Kemudian dijumlahkan dan ditambahkan dengan jumlah observasi. Pendekatan ini mengatur kesalahan peramalan yang besar karena kesalahan-kesalahan itu dikuadratkan. Metode itu menghasilkan kesalahan-kesalahan sedang yang kemungkinan lebih baik untuk kesalahan kecil, tetapi kadang menghasilkan perbedaan yang besar.

$$
\text { MSE }=\frac{\sum \mathrm{e}_{\mathrm{i}}^{2}}{\mathrm{n}}=\frac{\sum\left(\mathrm{X}_{\mathrm{i}}-\mathrm{F}_{\mathrm{i}}\right)^{2}}{\mathrm{n}}
$$

\section{SGD}

Gambar 3. MSE

Stochastic Gradient Descent (SGD) merupakan metode gradient descent yang melakukan update parameter untuk setiap data pelatihan $\mathrm{x}(\mathrm{i})$ dan label y(i) dan mempunyai persamaan dasar berikut :

$$
\theta=\theta-\eta \cdot \nabla_{\theta} J\left(\theta ; x^{(i)} ; y^{(i)}\right)
$$

Gambar 4. SGD

SGD seringkali melakukan update/pembaruan dengan varians yang tinggi, sehingga menyebabkan fungsi objektif meningkat secara tidak beraturan. Di satu sisi, hal ini dapat membuat loss function melompat ke titik minimal yang baru dan mempunyai potensi untuk melompat ke nilai minimum yang tidak pasti. Namun, hal ini dapat dicegah dengan mengurangi nilai learning rate, dan hasil SGD akan menuruni loss function ke titik minimum dengan optimal.

\section{Metode Penelitian}

Bagian ini menggambarkan bagaimana kerangka penelitian yang dilakukan agar sesuai dengan tujuan dan hasil yang diinginkan dengan waktu yang efisien. Adapun kerangka penelitian dapat dilihat pada gambar berikut:

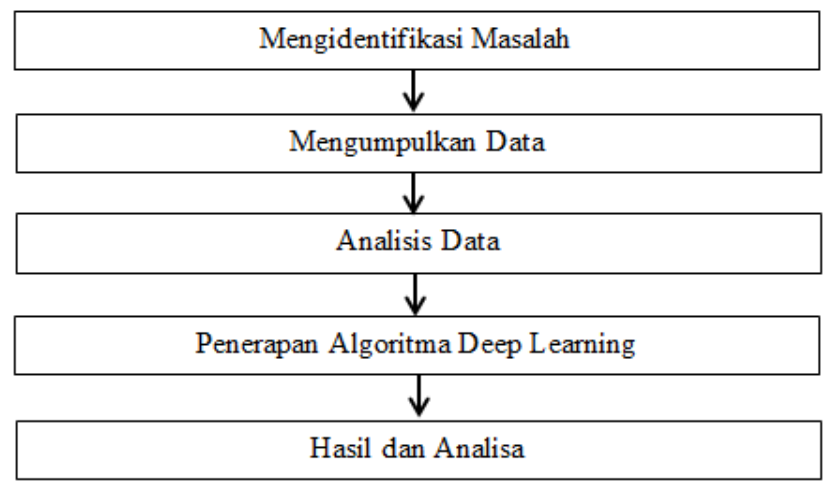

Gambar 5. Kerangka Kerja Penelitian

\section{Hasil dan Pembahasan}


Langkah-langkah penyelesaiannya:

\section{Menentukan Kriteria dan Pembobotan.}

Adapun kriteria dalam penelitian ini berdasarkan dari standar aspek penilaian Sekolah SMKS Mustafa Perbaungan. Berikut ini adalah kriteria-kriteria yang dijadikan patokan penilaian :

Tabel 1. kriteria dalam penelitian

\begin{tabular}{|c|c|c|c|}
\hline Variabel & Kriteria & Keterangan & $\begin{array}{c}\text { Nilai } \\
\text { Target }\end{array}$ \\
\hline A & Pengetahuan & Berkaitan dengan topik materi & 0.25 \\
\hline B & Keterampilan & $\begin{array}{c}\text { Berkaitan dengan kreativitas yang didapatkan } \\
\text { dari mata pelajaran }\end{array}$ & 0.25 \\
\hline C & Penilaian & Berkaitan dengan latihan uji pemahaman & 0.25 \\
\hline D & Antusias & Berkaitan dengan respons terhadap mata & 0.25 \\
\hline
\end{tabular}

\section{Penerapan Metode Backpropagation}

Data pada tabel diatas dari masing-masing atribut akan diberikan range tiap-tiap kriteria. Dalam metode Bacpropagation terdapat kriteria yang dibutuhkan untuk menentukan nilai hasil belajar siswa. Setiap kriteria akan direntangkan dan memiliki bentuk angka 0 sampai 1. Empat kriteria diatas ini adalah kriteriakriteria penting yang akan dijadikan bahan pertimbangan dalam menentukan standar pengambilan keputusan tingkat pemahaman siswa terhadap matapelajaran pemrograman, melalui proses perhitungan matematis. Adapun range terhadap masing-masing sub kriteria dapat dilihat pada tabel di bawah ini :

1. Kriteria Pengetahuan (A) Nilai 25

Tabel 2. Nilai Range Kriteria Pengetahuan

\begin{tabular}{|c|c|c|}
\hline Pengetahuan & Range Nilai & Bobot \\
\hline Sangat Memahami & $86-100$ & 1 \\
\hline Memahami & $76-85$ & 0.8 \\
\hline Cukup Memahami & $61-75$ & 0.6 \\
\hline Kurang Memahami & $31-60$ & 0.4 \\
\hline Tidak Memahami & $0-30$ & 0.2 \\
\hline
\end{tabular}

2. Kriteria Keterampilan (B) Nilai 25

Tabel 3. Nilai Range Kriteria Keterampilan

\begin{tabular}{|c|c|c|}
\hline Keterampilan & Range Nilai & Bobot \\
\hline Sangat Memahami & $86-100$ & 1 \\
\hline Memahami & $76-85$ & 0.8 \\
\hline Cukup Memahami & $61-75$ & 0.6 \\
\hline Kurang Memahami & $31-60$ & 0.4 \\
\hline Tidak Memahami & $0-30$ & 0.2 \\
\hline
\end{tabular}

3. Kriteria Penilaian (C) Nilai 25

Tabel 4. Nilai Range Kriteria Penilaian dan beban tugas

\begin{tabular}{|c|c|c|}
\hline Penilaian & Range Nilai & Bobot \\
\hline Sangat Baik & $86-100$ & 1 \\
\hline Baik & $76-85$ & 0.8 \\
\hline Cukup Baik & $61-75$ & 0.6 \\
\hline Kurang Memahami & $31-60$ & 0.4 \\
\hline Buruk & $0-30$ & 0.2 \\
\hline
\end{tabular}

4. Kriteria Antusias (D) Nilai 25

Tabel 5. Nilai Range Kriteria Antusias

\begin{tabular}{|c|c|c|}
\hline Antusias & Range Nilai & Bobot \\
\hline Sangat Antusias & $86-100$ & 1 \\
\hline Antusias & $76-85$ & 0.8 \\
\hline
\end{tabular}




\begin{tabular}{|c|c|c|} 
Cukup Antusias & $61-75$ & 0.6 \\
\hline Kurang Antusias & $31-60$ & 0.4 \\
\hline Tidak Antusias & $0-30$ & 0.2 \\
\hline
\end{tabular}

\section{Menentukan Alternatif}

Berikut ini adalah data 50 siswa/i pada penilaian penentuan tingkat pemahaman belajar siswa di SMKS Mustafa yang akan dijadikan alternative penilaian pada penelitian ini, namun peneliti menggunakan 5 sampel nama sebagai bahan perhitungan metode Backropagation dengan disimbolkan pada yaitu A1, A2, A3 sampai dengan A5.

\begin{tabular}{|c|c|c|c|c|c|c|}
\hline \multirow{2}{*}{ NO } & \multirow{2}{*}{ NAMA SISWA } & \multicolumn{5}{|c|}{ NILAI Pemnrograman } \\
\hline & & (A) & (B) & (C) & (D) & Rata-rata \\
\hline 1. & A1 & 75 & 80 & 75 & 83 & 78.25 \\
\hline 2. & A2 & 77 & 79 & 80 & 83 & 79.75 \\
\hline 3. & $\mathrm{~A} 3$ & 75 & 78 & 76 & 79 & 77 \\
\hline 4. & A4 & 83 & 85 & 77 & 79 & 81 \\
\hline 5. & A5 & 95 & 90 & 88 & 89 & 90.5 \\
\hline
\end{tabular}

\section{Melakukan Normalisasi Pada Data Alternatif}

Tabel 7. Normalisasi

\begin{tabular}{|c|c|c|c|c|}
\hline Nama Siswa & A & B & C & D \\
\hline A1 & C M & M & C B & A \\
\hline A2 & M & M & B & A \\
\hline A3 & C M & M & B & A \\
\hline A4 & M & M & B & A \\
\hline A5 & S M & S M & S B & S A \\
\hline
\end{tabular}

Data hasil penilaian siswa yang telah diubah kedalam nilai range dapat dilihat pada tabel dibawah ini

Tabel 8. konversi bobot nilai

\begin{tabular}{|c|c|c|c|c|}
\hline Nama Siswa & A & B & C & D \\
\hline A1 & 0.6 & 0.8 & 0.6 & 0.8 \\
\hline A2 & 0.8 & 0.8 & 0.8 & 0.8 \\
\hline A3 & 0.6 & 0.8 & 0.8 & 0.8 \\
\hline A4 & 0.8 & 0.8 & 0.8 & 0.8 \\
\hline A5 & 1 & 1 & 1 & 1 \\
\hline
\end{tabular}

\section{Fungsi Sigmoid}


Algoritma pelatihan backpropagation dengan menggunakan 4 input layer, 2 layer tersembunyi, 1 output layer dengan fungsi aktivasi sigmoid biner adalah sebagai berikut :

1. Tahap inisialisasi : Tuliskan nilai input yang diberikan

Tabel 9. Inisialisasi

\begin{tabular}{|c|c|c|c|c|c|}
\hline Nama Siswa & A & B & C & D & Learning Rate \\
\hline A1 & 0.6 & 0.8 & 0.6 & 0.8 & \multirow{2}{*}{1} \\
\cline { 1 - 4 } A2 & 0.8 & 0.8 & 0.8 & 0.8 & \multirow{2}{*}{1} \\
\hline A3 & 0.6 & 0.8 & 0.8 & 0.8 & \\
\hline A4 & 0.8 & 0.8 & 0.8 & 0.8 & \\
\hline A5 & 1 & 1 & 1 & 1 & \\
\hline
\end{tabular}

Berikan nilai bobot (V) dari input ke lapisan tersembunyi dengan nilai acak.

Tabel 10. Nilai Bobot dari Input ke Hidden Layer

\begin{tabular}{|c|c|c|}
\hline Kriteria & K1 & K2 \\
\hline A & 0.2 & -0.3 \\
\hline B & 0.4 & 0.1 \\
\hline C & 0.3 & -0.5 \\
\hline D & 0.5 & -0.4 \\
\hline
\end{tabular}

Berikan nilai bobot (W) dari lapisan tersembunyi ke output dengan nilai acak.

Tabel 11. Nilai Bobot dari Input ke Hidden Layer

\begin{tabular}{|c|c|}
\hline Kriteria & L \\
\hline K1 & -0.3 \\
\hline K2 & -0.2 \\
\hline
\end{tabular}

\section{Tahap Aktivasi}

a. Hitung keluaran tiap node (node tersembunyi dan node output)

1. Nama Siswa : A1

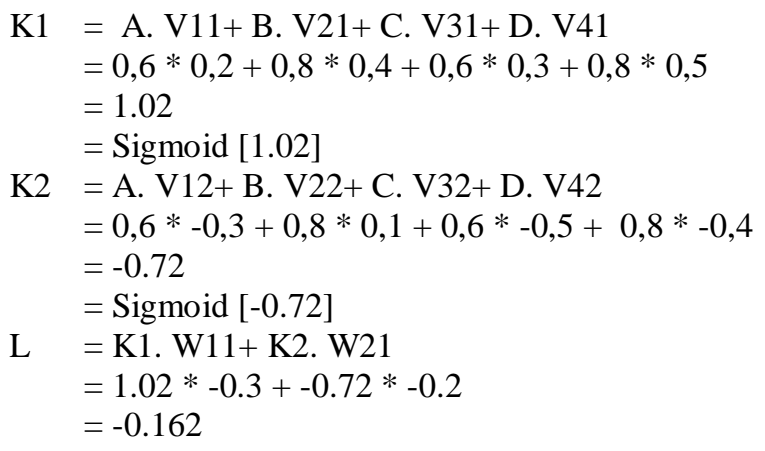

2. Nama Siswa : A2

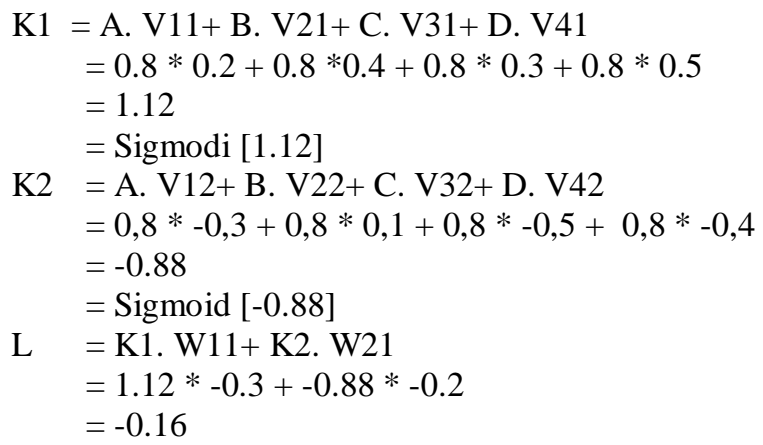




\section{Nama Siswa : A3}

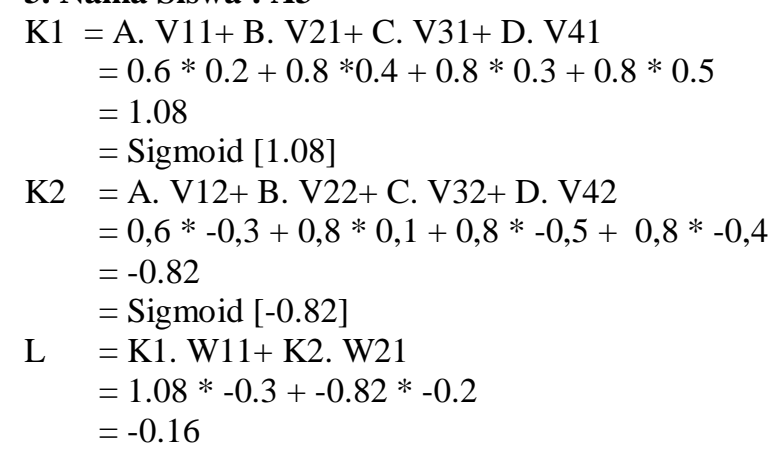

\section{Nama Siswa : A4}

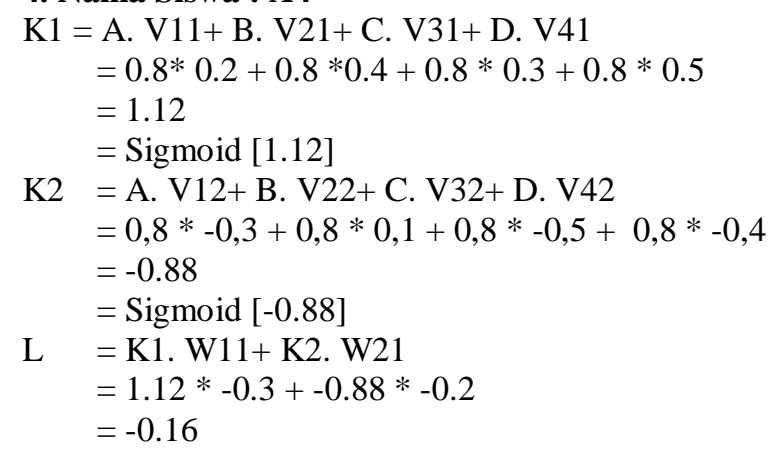

\section{Nama Siswa : A5}

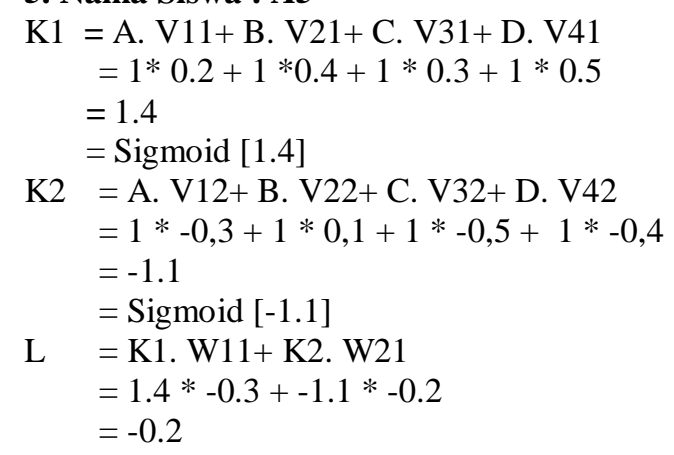

Tabel 12. Hasil Aktivasi

\begin{tabular}{|c|c|c|c|c|}
\hline No. & Nama Siswa & K1 & K2 & L \\
\hline 1. & A1 & 1.02 & -0.72 & -0.162 \\
\hline 2. & A2 & 1.12 & -0.88 & -0.16 \\
\hline 3. & A3 & 1.08 & -0.82 & -0.16 \\
\hline 4. & A4 & 1.12 & -0.88 & -0.16 \\
\hline 5. & A5 & 1.4 & -1.1 & -0.2 \\
\hline
\end{tabular}

\section{Tahap Menghitung Error Ouput dan Hidden Layer}

Gunakan Hasil Tabel aktivasi untuk melihatnya:

Tabel 13. Hasil Aktivasi 


\begin{tabular}{|c|c|c|c|c|}
\hline No. & Nama Siswa & K1 & K2 & $\mathrm{L}$ \\
\hline 1. & A1 & 1.02 & -0.72 & -0.162 \\
\hline 2. & A2 & 1.12 & -0.88 & -0.16 \\
\hline 3. & A3 & 1.08 & -0.82 & -0.16 \\
\hline 4. & A4 & 1.12 & -0.88 & -0.16 \\
\hline 5. & A5 & 1.4 & -1.1 & -0.2 \\
\hline
\end{tabular}

8. Menghitung Nilai Kepastian L, K1, K2

Tabel 14. Nilai Kepastian

\begin{tabular}{|c|c|c|c|c|}
\hline No. & Nama Siswa & L & K1 & K2 \\
\hline 1. & A1 & -0.04932 & -0.23524 & -0.08896 \\
\hline 2. & A2 & -0.04826 & -0.28759 & -0.12995 \\
\hline 3. & A3 & -0.04826 & -0.26644 & -0.11367 \\
\hline 4. & A4 & -0.04826 & -0.28759 & -0.12995 \\
\hline 5. & A5 & -0.072 & -0.41496 & -0.1989 \\
\hline
\end{tabular}

\section{Penentuan Keputusan}

Tabel 15. Nilai Keputusan

\begin{tabular}{|c|c|}
\hline Istilah & Range Nilai \\
\hline Memahami & $0.76-1$ \\
\hline Cukup Memahami & $0.51-0.75$ \\
\hline Kurang Memahami & $0.26-0.50$ \\
\hline Tidak Memahami & $0-0.25$ \\
\hline
\end{tabular}

Rumus : $=\mathrm{L}-\mathrm{K} 1-\mathrm{K} 2+0.25$ (Bobot Awal)

Tabel 16. Nilai Keputusan

\begin{tabular}{|c|c|c|c|c|c|}
\hline No. & Nama Siswa & L & K1 & K2 & Bobot Awal $(0,25)$ \\
\hline 1 & A1 & -0.0493 & -0.2352 & -0.089 & 0.52488 \\
\hline 2 & A2 & -0.0483 & -0.2876 & -0.13 & 0.61928 \\
\hline 3 & A3 & -0.0483 & -0.2664 & -0.1137 & 0.58185 \\
\hline 4 & A4 & -0.0483 & -0.2876 & -0.13 & 0.61928 \\
\hline 5 & A5 & -0.072 & -0.415 & -0.1989 & 0.79186 \\
\hline
\end{tabular}

\section{Perangkingan Hasil terurut dari 1 sampai 5}

Tabel 17. Hasil Urut

\begin{tabular}{|c|c|c|c|}
\hline No. & Nama Siswa & Rangking & Istilah \\
\hline 1 & A5 & 0.79186 & Memahami \\
\hline 2 & A4 & 0.61928 & Cukup Memahami \\
\hline 3 & A2 & 0.61928 & Cukup Memahami \\
\hline 4 & A3 & 0.58185 & Cukup Memahami \\
\hline
\end{tabular}




\begin{tabular}{|c|c|c|c|}
\hline No. & Nama Siswa & Rangking & Istilah \\
\hline 5 & A1 & 0.52488 & Cukup Memahami \\
\hline
\end{tabular}

\section{Kesimpulan}

1. Setelah dilakukan proses perhitungan maka didapatkan nama siswa A5 yang dikategorikan sebagai memahami pada mata pelajaran pemrograman.Selebihnya cukup memahami.

2. Rancangan penelitian ini dilakukan di tempat kerja penulis yang beralamat diDesa Lidah Tanah Dusun V Kecamatan Perbaungan, yaitu SMKS Mustafa.

3. Penulis bekerja sebagai guru pemrograman komputer.

4. Diaharapkan penelitian ini dapat memberikan gambaran tentang penerapan metode Deep Learning dalam memprediksi tingkat pemahaman siswa.

\section{Daftar Pustaka}

[1] R. Aulia, "Penerapan Metode Backpropagation Untuk Memprediksi Jumlah Kunjungan Wisatawan Berdasarkan Tingkat Hunian Hotel," Jurteksi, vol. 4, no. 2, pp. 115-122, 2018, doi: 10.33330/jurteksi.v4i2.45.

[2] D. I. S. Cikande, D. Stkip, and G. Smpn, "pemahaman siswa , pembelajaran IPA," vol. 10, no. 1, pp. 106116, 2016.

[3] D. C. Febrianto, "Penerapan Jaringan Saraf Tiruan dengan Metode Pembelajaran Backpropagation untuk Mengetahui Tingkat Kualifikasi Calon Siswa pada Sistem Informasi Penerimaan Siswa Baru di MAN 2 Banjarnegara," Juita, vol. II, pp. 189-197, 2013.

[4] Y. Hendawati and C. Kurniati, "Penerapan Metode Eksperimen Terhadap Pemahaman Konsep Siswa Kelas V Pada Materi Gaya Dan Pemanfatannya," Metod. Didakt., vol. 13, no. 1, 2017, doi: 10.17509/md.v13i1.7689.

[5] F. A. Hizham, Y. Nurdiansyah, and D. M. Firmansyah, "Implementasi Metode Backpropagation Neural Network (BNN) dalam Sistem Klasifikasi Ketepatan Waktu Kelulusan Mahasiswa (Studi Kasus: Program Studi Sistem Informasi Universitas Jember)," Berk. Sainstek, vol. 6, no. 2, p. 97, 2018, doi: 10.19184/bst.v6i2.9254.

[6] Y. A. Lesnussa, S. Latuconsina, and E. R. Persulessy, "Aplikasi Jaringan Saraf Tiruan Backpropagation untuk Memprediksi Prestasi Siswa SMA (Studi kasus: Prediksi Prestasi Siswa SMAN 4 Ambon)," J. Mat. Integr., vol. 11, no. 2, p. 149, 2015, doi: 10.24198/jmi.v11i2.9427.

[7] S. Maesaroh, "Peranan Metode Pembelajaran Terhadap Minat Dan Prestasi Belajar Pendidikan Agama Islam," J. Kependidikan, vol. 1, no. 1, pp. 150-168, 1970, doi: 10.24090/jk.v1i1.536.

[8] J. R. Mustakim, R. Ratianingsih, and D. Lusiyanti, "Prediksi Kualitas Air Bersih Pdam Kota Palu Menggunakan Metode Backpropagation," J. Ilm. Mat. Dan Terap., vol. 14, no. 1, pp. 47-55, 2017, doi: 10.22487/2540766x.2017.v14.i1.8353.

[9] V. Rahmayanti, "Pengaruh Minat Belajar Siswa dan Persepsi atas Upaya Guru dalam Memotivasi Belajar Siswa terhadap Prestasi Belajar Bahasa Indonesia Siswa SMP di Depok," SAP (Susunan Artik. Pendidikan), vol. 1, no. 2, pp. 206-216, 2016, doi: 10.30998/sap.v1i2.1027.

[10] S. Solikhun, M. Safii, and A. Trisno, "Jaringan Saraf Tiruan Untuk Memprediksi Tingkat Pemahaman Sisiwa Terhadap Matapelajaran Dengan Menggunakan Algoritma Backpropagation," J-SAKTI (Jurnal Sains Komput. dan Inform., vol. 1, no. 1, p. 24, 2017, doi: 10.30645/j-sakti.v1i1.26.

[11] N. P. Widiawati, K. Pudjawan, and I. G. Margunayasa, "Analisis pemahaman konsep dalam pembelajaran IPA pada siswa kelas IV SD di gugus II kecamatan banjar," e-Journal PGSD Univ. Pendidik. Ganesha, vol. $3, \quad$ no. $1, \quad$ pp. 12-14, 2015, [Online]. Available: https://ejournal.undiksha.ac.id/index.php/JJPGSD/article/view/5847.

[12] D. A. Yonanda, "Peningkatan Pemahaman Siswa Mata Pelajaran Pkn Tentang Sistem Pemerintahan Melalui Metode M2M (Mind Mapping) Kelas IV MI Mambaul Ulum Tegalgondo Karangploso Malang," J. Cakrawala Pendas, vol. 3, no. 1, 2017, doi: 10.31949/jcp.v3i1.410.

[13] D. A. Yonanda, "Peningkatan Pemahaman Siswa Mata Pelajaran PKN Tentang Sistem Pemenrintah," $J$. Cakrawala Pendas, vol. 3, no. 1, pp. 53-63, 2017.

[14] N. R. Lase and F. Riandari, "Perancangan Aplikasi Prediksi Jumlah Pendaftar Siswa Baru Dengan Metode Regresi Linier (Studi Kasus: SMA RK Deli Murni Bandar Baru)," J. Nas. Komputasi dan Teknol. Inf., vol. 3, no. 3, pp. 330-334, 2020. 
Jurnal Nasional Komputasi dan Teknologi Informasi

Vol. 4 No. 3, Juni 2021

P-ISSN 2620-8342

E-ISSN 2621-3052 